\title{
Konya kent merkezinde tüketicilerin margarin tüketimi üzerine etki eden faktörlerin analizi
}

Analysis of the factors affecting the margarine consumption of consumers in Konya city center

\author{
Pelin AVCI ${ }^{1}$ (iD), Mevlüt GÜL ${ }^{1}$ (D) \\ ${ }^{1}$ Isparta Uygulamalı Bilimler Üniversitesi, Ziraat Fakültesi, Tarım Ekonomisi Bölümü, Doğu Yerleşkesi, Isparta.
}

MAKALE BILGISI / ARTICLE INFO

Makale tarihçesi / Article history:

DOI: $10.37908 /$ mkutbd.868186

Geliş tarihi /Received:26.01.2021

Kabul tarihi/Accepted:15.04.2021

\section{Keywords:}

Margarine, consumption, logistic regression analysis, consumer, Konya.

Corresponding author: Pelin AVCI

$\bowtie$ : pelinavci42@outlook.com

\author{
ÖZET / A B STR A C T
}

Atıf / Citation: Avcı P, Gül M (2021) Konya kent merkezinde tüketicilerin margarin tüketimi üzerine etki eden faktörlerin analizi. MKU. Tar. Bil. Derg. 26(3) : 506-515. DOI: $10.37908 /$ mkutbd.868186

\section{GiRiş}

Yağlar, insan vücudu için karbonhidratlar ve proteinler kadar hayati öneme sahiptir. İnsanların gıda ihtiyacının karşılanması için gerekli olan temel ihtiyaç faktörlerinden biridir. Bu bağlamda doymuş yağ oranlarının az miktarda olması, hücre yapısı için ihtiyaç duyulan serbest yağ asitlerini bulundurması ve insan vücudunda bulunan yağda eriyen ( $A, D, E, K$ gibi) vitaminleri çözmede önemlidir. Ayrıca bitkisel yağlar, insan sağlığına faydalarının yanı sıra içerdikleri besin değerlerinin yüksek olması bakımından ayrı bir öneme sahiptir (Tosun, 2003).

Yağlar insan bedenindeki hücre, doku ve organların yapılarında yer almasından dolayı, hayatın devamlılığının sağlanması ve bedenin farklı fonksiyonlarını sıhhatli bir şekilde ifa etmesi için, kesinlikle alınması gerekli besin maddeleridir (Oğan ve Küçükkömürler, 2018).

Yağlar bitkisel ve hayvansal olmak üzere ikiye ayrılmaktadır. Çoğunlukla hayvansal yağlar oda sıcaklığında katı halde, bitkisel yağlar ise sıvı halde bulunmaktadır. Hayvansal yağlar tereyağı, iç yağı ve kuyruk yağı gibi yağları içermektedir (Özer ve ark., 2016). 
Bitkisel yağlar; ayçiçeği, mısır, kanola, susam, aspir gibi yağlı tohumlu bitkiler dışında zeytin, palm, yer fıstığı, fındık gibi yağı meyveler ve endüstriyel bitkilerden soya fasulyesi, pamuk çiğidi ve haşhaşın işlenmesiyle elde edilen yağlardır (Polat, 2010).

Günümüzde insanların besin ihtiyaçlarını karşılayabilmek için kullandıkları yağların \%95'ini bitkisel kaynaklı yağlar oluşturmaktadır (Torun, 2013). Nüfus artışı yağ talebini de arttırmaktadır. Türkiye'de en çok tüketilen ve tercih edilen bitkisel yağ ayçiçeği yağıdır (Karlı ve ark., 2018; Kadakoğlu ve Karlı, 2019). Bitkisel yağların hayvansal yağlara oranla daha fazla doymuş yağ asitlerini içermesi nedeniyle bitkisel yağların insan beslenmesindeki etkisini daha fazla artırmaktadır (Öztekin, 2006). Normal bir insan günlük faaliyetlerini idame ettirebilmesi için yaklaşık olarak 2800-3000 kaloriye intiyaç duymaktadır. Bunun \%30-35'ini yani 850-1000 kalorisini yağlardan alması gerekmektedir. Bir insanın günde $95 \mathrm{gr}$ yağ tüketmesi gerektiği ifade edilmektedir. Bu rakam yılda kişi başına $23 \mathrm{~kg}$ yağ tüketimine tekabül etmektir (MEB, 2016).

Margarin renk, lezzet ve yapı olarak tereyağına benzeyen bir emülsiyondur. Çeşitli bitkisel sıvı yağlar, süt, yoğurt, peynir suyu tozu, su vitamin gibi maddeler kullanılarak hazırlanmaktadır. Margarinleri değişen oranda yağ içerikli kompozisyonları ve farklı üretim yöntemleri ile farklı türlerini üretmek mümkün olmaktadır. Kahvaltılık margarinler ile yemek ve endüstriyel ürünlerde kullanılan margarinler olarak sınıflandırma mümkündür (ÇBS, 2020). Türkiye kişi başına yıllık margarin tüketimi $2.2 \mathrm{~kg}$ dır (Baltacı, 2011).

Köksal (1993) ve Beyhan (2004) sıvı yağların (zeytinyağı ve diğer bitkisel yağlar) ve katı yağların (tereyağı, margarin) dengeli olarak tüketilmesi gerektiğini ifade etmişlerdir. Sözen ve ark. (2009) metal sektöründe bir işyerinde çalışan 278 işçinin her gün katı margarin tüketimi oranını \%6.2, yumuşak margarin tüketimi oranını \%7.9 olarak bulmuşlardır. Azabağaoğlu ve ark. (2003), İstanbul ilinde bitkisel yağ tüketimini kişi başına yıllık 18.39 kg olarak hesap etmişlerdir. Gelir gruplarında, hanelerde bitkisel yağ tüketimi birbirine yakındır. Şengül (2002) ve Akbay (2005), bitkisel ve hayvansal yağların gelir elastikiyetlerini pozitif hesaplamışlar ve gelir artışının bitkisel yağ tüketim miktarında oransal artışa sebep olduğunu tespit etmişlerdir. Gündüz ve Esengün (2010) Samsun ilinde hanehalklarında yıllık kişi başına bitkisel yağ tüketimini $18 \mathrm{~kg}$ olarak tespit etmişler ve en fazla ayçiçeği yağının tüketildiğini saptamışlardır. Baltacı (2011), Ankara ilindeki tüketicilerin \%65.55'nin her zaman aynı margarin markasını tercih ettiğini, \%87.39'u marka tercih sebeplerinin kalite olduğunu ve $\% 40.76$ 's ise marka tercih sebeplerinin fiyat olduğunu saptamıştır.
Sizege (2017) Türkiye'de hanelerin margarin tüketim oranını \%24.26 olarak hesaplamıştır. Yen ve ark. (2002) $A B D$ 'de margarin tüketim oranını \%81 bulmuştur. Kim (2008) ise ABD'de besin bilgileri, ambalaj boyutu ve ürün formları gibi ürün özelliklerinin ve hane halkı geliri ve yaş kompozisyonunun margarin talebinin önemli belirleyicileri olduğunu saptamıştır. Ali ve ark. (2013), Pakistan'da hanelerde yemeklik yağ tüketimini etkileyen faktörlerin; gelir artışı, nüfus artışı, kentleşme, marka olduğunu saptamıştır. Yağın fiyatı, gelir, aile büyüklüğü, yağ tüketim fonksiyonunu önemli ölçüde etkilediğini ortaya koymuşlardır.

Bu çalışmada margarin tüketimi üzerine etki eden faktörlerin Lojistik regresyon analizi yöntemiyle analizi amaçlanmıştır.

\section{MATERYAL ve YÖNTEM}

Çalışma ana materyalini; Konya ili merkez ilçelerinde (Selçuklu, Meram, Karatay) ikamet eden tüketicilerden elde edilen veriler oluşturmuştur. Veriler 2019 Nisan döneminde toplanmıştır. Araştırmada örnek sayısı belirlemek için Anakitle Oranlarına Dayalı Basit Tesadüfi Olasılık Örneklemesi "Sonlu Anakitle" formülünden yararlanılmıştır (Miran, 2011).

$\mathrm{n}=\mathrm{x}=(\mathrm{Np}(1-\mathrm{p})) /\left((\mathrm{N}-1) \sigma \mathrm{px} \mathrm{x}^{2} \mathrm{P}(1-\mathrm{p})\right)$

$\mathrm{n}$ : Örnek hacmi

$\mathrm{N}$ : Örnekleme kapsamındaki toplam kişi

p: Tahmin oranı

$\sigma \mathrm{px}^{2}$ : Oranın varyansı

p'nin değeri 0.5 alınmıştır. Örnek hacmi \%95 güven aralığında ve \%5 hata payı hesaplanmıştır. Buna göre örneklem büyüklüğü 384 olarak saptanmıştır. Çalışmada veri toplamak amacıyla yüz yüze anket tekniği uygulanmıştır. Örnekleme sonucunda bulunan örnek sayıları, Selçuklu ilçesindeki mahallelerden toplam 189 tüketici, Meram ilçesindeki mahallelerden toplam 100, Karatay ilçesindeki mahallelerden toplam 95 tüketici şeklinde mahalle nüfuslarına göre dağıtılmış ve bu şekilde veriler elde edilmiştir.

Margarin tüketimi üzerinde etkili olan faktörler Lojistik regresyon analizi yöntemiyle analiz edilmiştir. Lojistik regresyon, bir bağımlı değişken ile en iyi uyuma sahip olabilecek bir veya daha fazla açıklayıcı değişkenler arasındaki ilişkiyi test eden bir analiz yöntemidir. Bağımlı değişken kategorik olmaktadır (Aktaş ve Erkuş, 2009).

Lojistik fonksiyonun 0 ile 1 arasında bir değişim aralığına sahip olması Lojistik fonksiyonun tercih edilmesinde önemli etkendir (Hosmer ve Lemeshow, 1980).

Lojistik regresyon modelinde olayın meydana gelmesi durumu 1 , meydana gelmemesi durumu 0 ile ifade 
edilmektedir (Bircan, 2004). Margarin tüketiminde etkileyen sosyo-demografik faktörlerin belirlenmesi amacıyla bu model kullanılmıştır. Tahmin edilen modelde margarin tüketim durumu bağımlı değişken olarak tanımlanmıştır.

\section{BULGULAR ve TARTIŞMA}

\section{Tüketicilerin demografik özellikleri}

Konya ilinde yapılan anket çalışması sonucunda görüşülen 384 bireyin ortalama aylık aile geliri toplam 4906 TL'dir. Birinci gelir grubunda aylık ortalama gelir $2541 \mathrm{TL}$, ikinci gelir grubunda 5036 TL ve üçüncü gelir grubunda 10676 TL olduğu saptamıştır(Şekil 1).

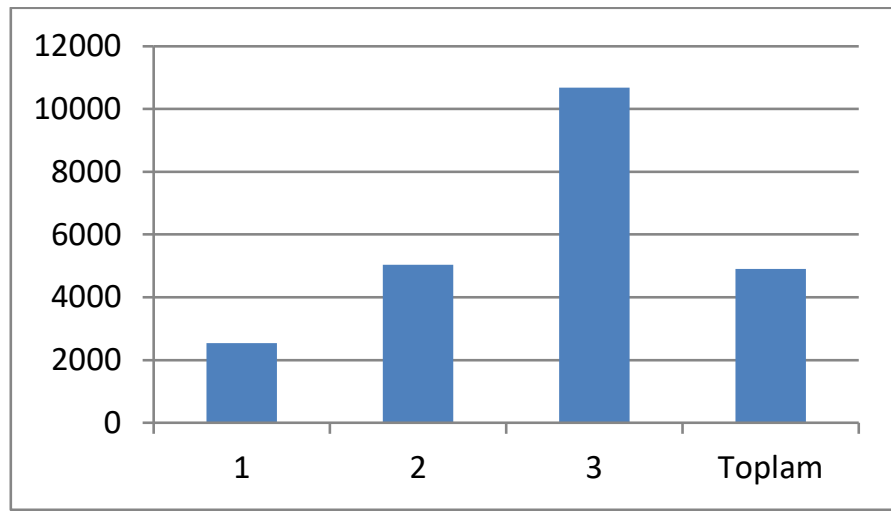

Şekil 1. Tüketicilerin aylık geliri(TL).

Figure 1. Consumers' monthly income (TRL).

Ankete katılan kişilerin aylık ortalama harcamaları toplam 3992 TL'dir. Gelir grupları içerisinde aylık harcama birinci gelir grubunda $2430 \mathrm{TL}$, ikinci gelir grubunda $4131 \mathrm{TL}$, üçüncü gelir grubunda ise $7620 \mathrm{TL}$ olarak tespit edilmiştir(Şekil 2).

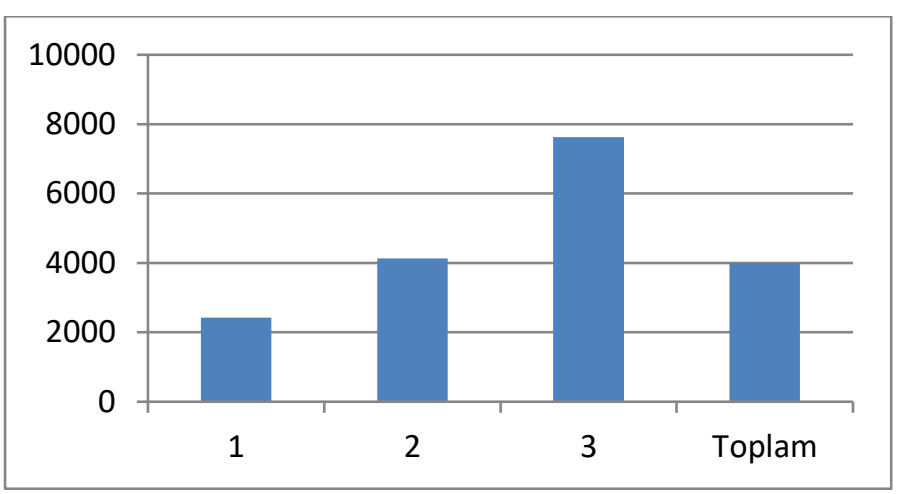

Şekil 2. Tüketicilerin aylık harcaması (TL).

Figure 2. Consumers' monthly spending (TRL).

Görüşülen bireylerin aylık ortalama gıda harcaması toplam 1323 TL bulunmuştur. Gelir gruplarına göre en düşük gıda harcaması 816 TL ile birinci gelir grubunda iken, en fazla 2433 TL ile üçüncü gelir grubunda olduğu saptanmıştır(Şekil 3).

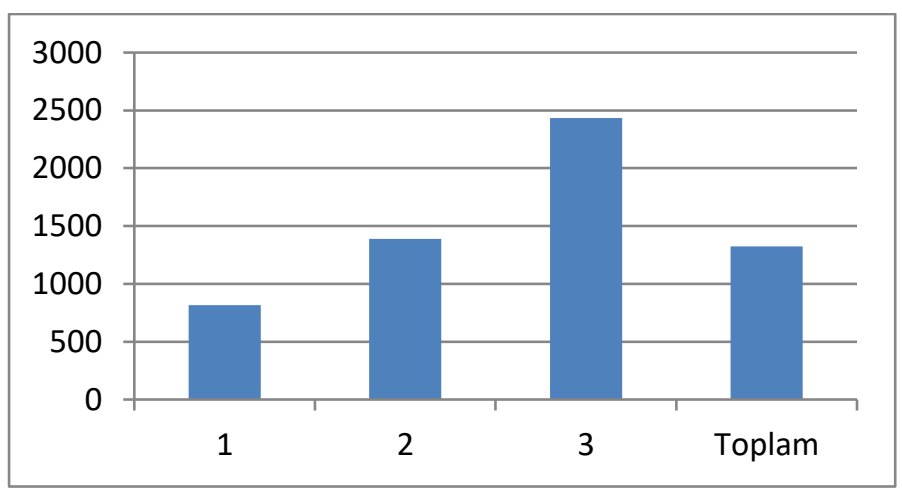

Şekil 3. Tüketicilerin aylık gıda harcaması (TL).

Figure 3. Consumers' monthly food expenditure (TRL).

Araştırmaya katılan bireylerin cinsiyetlerine ilişkin sonuçlar Çizelge 1 'de verilmiştir. Buna göre tüketicilerin \%65.63'ünün kadın, \%34.37'sinin ise erkek olduğu gözlemlenmiştir. Genel olarak incelendiğinde kadın katılımcıların sayısının erkeklerden daha fazla olduğu görülmüştür.

Çizelge 1. Tüketicilerin cinsiyeti

Table 1. Consumers' gender

\begin{tabular}{ccccccccc}
\hline \multirow{2}{*}{ Cinsiyet } & \multicolumn{9}{c}{ Gelir grupları } & \multicolumn{2}{c}{ Toplam } \\
\cline { 2 - 7 } & \multicolumn{2}{c}{$\mathrm{I}(1000-3500 \mathrm{TL})$} & \multicolumn{1}{c}{$\mathrm{II}(3501-7500 \mathrm{TL})$} & $\mathrm{III}(7501+\mathrm{TL})$ & & \\
\cline { 2 - 8 } & $\mathrm{N}$ & $\%$ & $\mathrm{~N}$ & $\%$ & $\mathrm{~N}$ & $\%$ & $\mathrm{~N}$ & $\%$ \\
\hline Kadın & 99 & 69.72 & 122 & 64.89 & 31 & 57.41 & 252 & 65.63 \\
\hline Erkek & 43 & 30.28 & 66 & 35.11 & 23 & 42.59 & 132 & 34.37 \\
\hline Toplam & 142 & 100.00 & 188 & 100.00 & 54 & 100.00 & 384 & 100.00 \\
\hline
\end{tabular}

Çalışmada görüşülen bireylerin yaş grupları Çizelge 2'de verilmiştir. Genel ortalamaya göre, \%29.95'lik kısmın 4150 yaş aralığında olduğu, \%3.65'lik kısmın ise 61 yaş ve üzerinde olduğu saptanmıştır. $31-40$ yaş ve $41-50$ yaş gruplarının katılımının daha fazla olduğu belirlenmiştir. 
Çizelge 2. Tüketicilerin yaşı

Table 2: Age of consumers

\begin{tabular}{|c|c|c|c|c|c|c|c|c|}
\hline \multirow{3}{*}{ Yaş grupları } & \multicolumn{6}{|c|}{ Gelir grupları } & \multirow{2}{*}{\multicolumn{2}{|c|}{ Toplam }} \\
\hline & \multicolumn{2}{|c|}{ I (1000-3500 TL) } & \multicolumn{2}{|c|}{ II (3501-7500 TL) } & \multicolumn{2}{|c|}{ III (7501+ TL) } & & \\
\hline & $\mathrm{N}$ & $\%$ & $\mathrm{~N}$ & $\%$ & $\mathrm{~N}$ & $\%$ & $\mathrm{~N}$ & $\%$ \\
\hline $18-25$ & 10 & 7.04 & 15 & 7.98 & 0 & 0.00 & 25 & 6.51 \\
\hline $26-30$ & 20 & 14.08 & 33 & 17.55 & 5 & 9.26 & 58 & 15.10 \\
\hline $31-40$ & 41 & 28.87 & 50 & 26.60 & 18 & 33.33 & 109 & 28.39 \\
\hline $41-50$ & 33 & 23.24 & 60 & 31.91 & 22 & 40.74 & 115 & 29.95 \\
\hline $51-60$ & 26 & 18.31 & 28 & 14.89 & 9 & 16.67 & 63 & 16.41 \\
\hline $61+$ & 12 & 8.45 & 2 & 1.06 & 0 & 0.00 & 14 & 3.65 \\
\hline Toplam & 142 & 100.00 & 188 & 100.00 & 54 & 100.00 & 384 & 100.00 \\
\hline
\end{tabular}

Çalışmada görüşülen bireylerin gelir gruplarına göre nerede doğdukları Çizelge 3'te ele alınmış ve çoğunlukla büyükşehirde doğmuş oldukları gözlemlenmiştir.
Çizelgeden de incelenebileceği gibi en yüksek oranın \%60.42 ile büyükşehirde doğanların olduğu, bunu sırasıyla ilçe, il merkezi ve köyde doğanlar izlemiştir.

Çizelge 3. Tüketicilerin doğum yeri

Table 3. Birth place of consumers

\begin{tabular}{|c|c|c|c|c|c|c|c|c|}
\hline \multirow{3}{*}{ Doğum yeri } & \multicolumn{6}{|c|}{ Gelir grupları } & \multirow{2}{*}{\multicolumn{2}{|c|}{ Toplam }} \\
\hline & \multicolumn{2}{|c|}{ I (1000-3500 TL) } & \multicolumn{2}{|c|}{ II (3501-7500 TL) } & \multicolumn{2}{|c|}{ III $(7501+T L)$} & & \\
\hline & $\mathrm{N}$ & $\%$ & $\mathrm{~N}$ & $\%$ & $\mathrm{~N}$ & $\%$ & $\mathrm{~N}$ & $\%$ \\
\hline Büyükşehir & 84 & 59.15 & 117 & 62.23 & 31 & 57.41 & 232 & 60.42 \\
\hline il merkezi & 17 & 11.97 & 33 & 17.55 & 8 & 14.81 & 58 & 15.10 \\
\hline İlçe & 26 & 18.31 & 21 & 11.17 & 13 & 24.07 & 60 & 15.63 \\
\hline Köy & 15 & 10.56 & 17 & 9.04 & 2 & 3.70 & 34 & 8.85 \\
\hline Toplam & 142 & 100.00 & 188 & 100.00 & 54 & 100.00 & 384 & 100.00 \\
\hline
\end{tabular}

Çizelge 4'te görüşülen bireylerin eğitim düzeyi gösterilmektedir. Görüşme yapılan hane halklarındaki bireylerin \%28.91'inin lise mezunu, \%4.95'inin ise lisansüstü mezunu olduğu belirlenmiştir. Lisansüstü mezununun en fazla olduğu grup \%12.96 ile üçüncü grup iken lise mezununun en fazla olduğu birinci gruptur. Lise ve lisans mezunlarının katıımı daha fazladır.

Çizelge 4. Tüketicilerin eğitim düzeyi

Table 4. Education level of consumers

\begin{tabular}{|c|c|c|c|c|c|c|c|c|}
\hline \multirow{3}{*}{ Eğitim düzeyi } & \multicolumn{6}{|c|}{ Gelir grupları } & \multirow{2}{*}{\multicolumn{2}{|c|}{ Toplam }} \\
\hline & \multicolumn{2}{|c|}{$\mathrm{I}(1000-3500 \mathrm{TL})$} & \multicolumn{2}{|c|}{ II (3501-7500 TL) } & \multicolumn{2}{|c|}{ III (7501+ TL) } & & \\
\hline & $\mathrm{N}$ & $\%$ & $\mathrm{~N}$ & $\%$ & $\mathrm{~N}$ & $\%$ & $\mathrm{~N}$ & $\%$ \\
\hline ílkokul & 38 & 26.76 & 21 & 11.17 & 4 & 7.41 & 63 & 16.41 \\
\hline Ortaokul & 29 & 20.42 & 19 & 10.11 & 5 & 9.26 & 53 & 13.80 \\
\hline Lise & 45 & 31.69 & 60 & 31.91 & 6 & 11.11 & 111 & 28.91 \\
\hline Ön lisans & 19 & 13.38 & 33 & 17.55 & 6 & 11.11 & 58 & 15.10 \\
\hline Lisans & 8 & 5.63 & 46 & 24.47 & 26 & 48.15 & 80 & 20.83 \\
\hline Lisansüstü & 3 & 2.11 & 9 & 4.79 & 7 & 12.96 & 19 & 4.95 \\
\hline Toplam & 142 & 100.00 & 188 & 100.00 & 54 & 100.00 & 384 & 100.00 \\
\hline
\end{tabular}

Çalışmada görüşülen bireylerin medeni durumları hakkındaki bilgiler Çizelge 5'te verilmiştir. Elde edilen verilere göre ankete katılanların \%76.04'ü evli çocuklu, \%17.45'i bekâr, \%6.51'inin ise evli çocuksuz olduğu tespit edilmiştir. 
Çizelge 5. Tüketicilerin medeni durumları

Table 5. Consumers' marital status

\begin{tabular}{|c|c|c|c|c|c|c|c|c|}
\hline \multirow{3}{*}{ Medeni durum } & \multicolumn{6}{|c|}{ Gelir grupları } & \multirow{2}{*}{\multicolumn{2}{|c|}{ Toplam }} \\
\hline & \multicolumn{2}{|c|}{ I (1000-3500 TL) } & \multicolumn{2}{|c|}{ II (3501-7500 TL) } & \multicolumn{2}{|c|}{ III (7501+ TL) } & & \\
\hline & $\mathrm{N}$ & $\%$ & $\mathrm{~N}$ & $\%$ & $\mathrm{~N}$ & $\%$ & $\mathrm{~N}$ & $\%$ \\
\hline Evli çocuksuz & 12 & 8.45 & 11 & 5.85 & 2 & 3.70 & 25 & 6.51 \\
\hline Evli çocuklu & 112 & 78.87 & 134 & 71.28 & 46 & 85.19 & 292 & 76.04 \\
\hline Bekâr & 18 & 12.68 & 43 & 22.87 & 6 & 11.11 & 67 & 17.45 \\
\hline Toplam & 142 & 100.00 & 188 & 100.00 & 54 & 100.00 & 384 & 100.00 \\
\hline
\end{tabular}

Çalışmada bireylerin meslek grupları altı gruba ayrılarak Çizelge $6^{\prime}$ da incelenmiştir. Görüşülen bireylere meslekleri sorulduğunda \%34.11'inin ev hanımı olduğu, $\% 27.08$ 'inin serbest meslekle uğraştığı, \%16.41'inin ise memur olduğu tespit edilmiştir. Gelir grupları olarak incelendiğinde ise birinci gelir grubunda \%50.00 ile ev hanımı meslek grubunun yoğunlukta olduğu, bunu \%15.49 oranı ile işçilerin takip ettiği hesap edilmiştir. Üçüncü gelir grubunun çoğunluğunu ise memurlar oluşturmaktadır.

Çizelge 6. Tüketicilerin meslek grupları

Table 6. Consumers' professional groups

\begin{tabular}{|c|c|c|c|c|c|c|c|c|}
\hline \multirow{3}{*}{ Meslek grupları } & \multicolumn{6}{|c|}{ Gelir grupları } & \multirow{2}{*}{\multicolumn{2}{|c|}{ Toplam }} \\
\hline & \multicolumn{2}{|c|}{ I (1000-3500 TL) } & \multicolumn{2}{|c|}{ II (3501-7500 TL) } & \multicolumn{2}{|c|}{ III (7501+ TL) } & & \\
\hline & $\mathrm{N}$ & $\%$ & $\mathrm{~N}$ & $\%$ & $\mathrm{~N}$ & $\%$ & $\mathrm{~N}$ & $\%$ \\
\hline Memur & 0 & 0.00 & 35 & 18.62 & 28 & 51.85 & 63 & 16.41 \\
\hline İşçi & 22 & 15.49 & 11 & 5.85 & 1 & 1.85 & 34 & 8.85 \\
\hline Serbest meslek & 20 & 14.08 & 66 & 35.11 & 18 & 33.33 & 104 & 27.08 \\
\hline Emekli & 18 & 12.68 & 5 & 2.66 & 1 & 1.85 & 24 & 6.25 \\
\hline Ev hanımı & 71 & 50.00 & 54 & 28.72 & 6 & 11.11 & 131 & 34.11 \\
\hline Çalışmıyor & 11 & 7.75 & 17 & 9.04 & 0 & 0.00 & 28 & 7.29 \\
\hline Toplam & 142 & 100.00 & 188 & 100.00 & 54 & 100.00 & 384 & 100.00 \\
\hline
\end{tabular}

Bu araştırmada, bireylerin \%60.16'ık oranı ev sahibi olduğunu belirtmişlerdir. Geriye kalan \%39.32'lik kısım ise aylık gelirlerinin bir kısmını kira harcamalarına ayırmaktadırlar (Çizelge 7).

Çizelge 7. Tüketicilerin ikamet şekli

Table 7. Consumers' way of residence

\begin{tabular}{|c|c|c|c|c|c|c|c|c|}
\hline \multirow{3}{*}{ İkamet şekli } & \multicolumn{6}{|c|}{ Gelir grupları } & \multirow{2}{*}{\multicolumn{2}{|c|}{ Toplam }} \\
\hline & \multicolumn{2}{|c|}{ I (1000-3500 TL) } & \multicolumn{2}{|c|}{ II (3501-7500 TL) } & \multicolumn{2}{|c|}{ III (7501+ TL) } & & \\
\hline & $\mathrm{N}$ & $\%$ & $\mathrm{~N}$ & $\%$ & $\mathrm{~N}$ & $\%$ & $\mathrm{~N}$ & $\%$ \\
\hline Kira & 59 & 41.55 & 77 & 40.96 & 15 & 27.78 & 151 & 39.32 \\
\hline Kendi evi & 82 & 57.75 & 110 & 58.51 & 39 & 72.22 & 231 & 60.16 \\
\hline Diğer & 1 & 0.70 & 1 & 0.53 & 0 & 0.00 & 2 & 0.52 \\
\hline Toplam & 142 & 100.00 & 188 & 100.00 & 54 & 100.00 & 384 & 100.00 \\
\hline
\end{tabular}

\section{Margarin tüketimine etki eden faktörlerin analizi}

Bu bölümde margarin tüketiminde etkili olan faktörlerin belirlenmesi amacıyla yapılan lojistik regresyon modeline ait sonuçlara yer verilmiştir. İkili (binary) lojistik regresyon modelinde kullanılan bağımsız değişkenler ve değişkenlere ilişkin tanımlamalar Çizelge 8 'de verilmiştir. 
Çizelge 8. Margarin modelinde kullanılan değişkenlere ilişkin açıklamalar Table 8. Explanations on the variables used in the margarine model

\begin{tabular}{|c|c|c|}
\hline \multirow{2}{*}{\multicolumn{2}{|c|}{$\begin{array}{l}\text { Kullanılan değişkenler } \\
\text { Bağımlı değisken }\end{array}$}} & \multirow[t]{2}{*}{ Değişkenlere ilişkin açıklamalar } \\
\hline & & \\
\hline Margarin yağı tüketimi & Kategorik & $\begin{array}{l}\text { 0:Margarin yağı tüketmeyen } \\
\text { 1:Margarin yağı tüketen }\end{array}$ \\
\hline \multicolumn{3}{|l|}{ Bağımsız değişkenler } \\
\hline Cinsiyet & Kategorik & $\begin{array}{l}\text { 0: Erkek } \\
\text { 1: Kadın }\end{array}$ \\
\hline Yaş 1 & Kategorik & $\begin{array}{l}0: 9 \text { yaş üstü } \\
1: 9 \text { yaş altı }\end{array}$ \\
\hline Yaş 2 & Kategorik & $\begin{array}{l}0: 40 \text { yaş üstü } \\
\text { 1: } 40 \text { yaş altı }\end{array}$ \\
\hline Yaş 3 & Kategorik & $\begin{array}{l}0: 60 \text { yaş üstü } \\
\text { 1: } 60 \text { yaş altı }\end{array}$ \\
\hline Doğum yeri & Kategorik & $\begin{array}{l}\text { 0: Büyükşehirde doğmayanlar } \\
\text { 1: Büyükşehirde doğanlar }\end{array}$ \\
\hline Eğitim & Kategorik & $\begin{array}{l}\text { 0: Orta ve üstü } \\
\text { 1: Orta ve altı }\end{array}$ \\
\hline Medeni durum & Kategorik & $\begin{array}{l}\text { 0: Evli çocuklu olmayanlar } \\
\text { 1:Evli çocuklu olanlar }\end{array}$ \\
\hline Gelir 1 & Kategorik & $\begin{array}{l}\text { 0:Düşük gelirli olmayanlar } \\
\text { 1:Düşük gelirli olanlar }\end{array}$ \\
\hline Gelir 2 & Kategorik & $\begin{array}{l}\text { 0:Yüksek gelirli olanlar } \\
\text { 1:Yüksek gelirli olmayanlar }\end{array}$ \\
\hline Hane büyüklüğü & Sürekli & Birey sayısı \\
\hline Hane harcaması & Sürekli & $\mathrm{TL}$ \\
\hline Gıda harcaması & Sürekli & TL \\
\hline
\end{tabular}

Çizelge 9 incelendiğinde ilk sınıflandırma sonuçları doğrultusunda margarin tüketenlerin \%0.0, tüketmeyenlerin \%100'ü doğru tahmin edilmiştir. Doğru sınıflandırma yüzdesi \%65.9'dur. Margarin tüketme başlangıç modelinde yer almayan değişkenler, modelin bağımsız değişkenleridir. Sabit değerin istatistikleri incelendiğinde sabit anlamlı bulunmuş ve katsayı değeri $-0,658$ olarak bulunmuştur.

Çizelge 9. Başlangıç çözümde yer alan değişken

Table 9. The variable included in the initial solution

\begin{tabular}{|c|c|c|c|c|}
\hline \multirow{3}{*}{\multicolumn{2}{|c|}{ Gerçek/Gözlenen durum }} & \multicolumn{3}{|l|}{ Kestirilen durum } \\
\hline & & \multicolumn{2}{|c|}{ Margarin Tüketimi } & \multirow{2}{*}{-Doğru Sınıflandırma Yüzdesi } \\
\hline & & Tüketmeyen(0) & Tüketen(1) & \\
\hline \multirow{2}{*}{ Margarin Tüketimi } & Tüketmeyen(0) & 253 & 0 & 100.0 \\
\hline & Tüketen(1) & 131 & 0 & 0.0 \\
\hline \multicolumn{2}{|c|}{ Toplam doğru sınıflandırma yüzdesi } & \multicolumn{3}{|c|}{65.9} \\
\hline
\end{tabular}

\section{Sabit değerin istatistikleri}

B

Standart hata

Walt

0.108

Sd

$P$ 
Çizelge 10 'da sunulan başlangıç modelinde yer almayan değişkenler araştırmanın bağımsız değişkenleridir. Başlangıç modelinde eşitlikte yer almayan değişkenler tablosunda önemli olan hata Ki-kare istatistiğidir. İlk Kikare değeri olarak da adlandırılan bu değer anlamlı bulunmuştur $\left[\mathrm{x}^{2 \beta}{ }_{0}=53.225, \mathrm{p}<0.05\right]$. Dolayısıyla modelde yer almayan değişkenlerin bağımlı değişkeni tahminleme gücünü anlamlı bir şekilde artıracağını ifade etmektedir. Diğer bir ifade ile modele ek bağımsız değişkenlerin eklenmesi gerekliliğini bildirmektedir.

Çizelge 10. Başlangıç çözümde yer almayan değişkenler

Table 10. Variables not included in the initial solution

\begin{tabular}{llll}
\hline Değişkenler & Skor & sd & P \\
\hline Cinsiyet & 4.189 & 1.000 & 0.041 \\
\hline Yaş 1 & 5.707 & 1.000 & 0.017 \\
\hline Yaş 2 & 0.104 & 1.000 & 0.747 \\
\hline Yaş 3 & 2.315 & 1.000 & 0.128 \\
\hline Doğum yeri & 4.987 & 1.000 & 0.026 \\
\hline Eğitim & 10.162 & 1.000 & 0.001 \\
\hline Medeni durum & 6.079 & 1.000 & 0.014 \\
\hline Gelir 1 & 5.541 & 1.000 & 0.019 \\
\hline Gelir 2 & 10.413 & 1.000 & 0.001 \\
\hline Hane büyüklüğü & 13.916 & 1.000 & 0.000 \\
\hline Hane harcaması & 2.456 & 1.000 & 0.117 \\
\hline Gıda harcaması & 4.890 & 1.000 & 0.027 \\
\hline Hata Ki-kare istatistiği $\mathbf{( \mathbf { x } ^ { \mathbf { 2 } } \mathbf { o } )}$ & $\mathbf{5 3 . 2 2 5}$ & $\mathbf{1 2 . 0 0 0}$ & $\mathbf{0 . 0 0 0}$
\end{tabular}

Çizelge 11 'de margarin için elde edilen lojistik regresyon model sonucunda sınıflandırma verilmiştir. Buna göre bağımsız değişkenlerin dâhil edildiği sınıflandırma ile margarin tüketmeyen grubunda olan 253 tüketiciden 224'ü doğru, 29'u yanlış sınıflandırılmış olup, doğru sınıflandırılma oranı \%85.5'dır. Margarin tüketen 131 tüketiciden 46 'sı doğru, 85'i yanlış sınıflandırımış olup, doğru sınıflandırma oranı \%35.1'dir. Amaçlanan modele ilişkin toplam doğru sınıflandırma oranı ise \%70.3'dur.

Çizelge 11. Margarin için elde edilen model sonucunda sınıflandırma

Table 11. Classification as a result of the model obtained for margarine Gerçek/Gözlenen durum

Kestirilen durum Margarin Tüketimi Tüketmeyen(0) Tüketen(1)

\begin{tabular}{llccc}
\hline Margarin & Tüketmeyen(0) & 224 & 29 & 88.5 \\
\cline { 2 - 5 } Tüketimi & Tüketen(1) & 85 & 46 & 35.1 \\
\hline Toplam doğru sınıflandırma yüzdesi & & & 70.3 \\
\hline
\end{tabular}

Çizelge 12 'de margarin yağı tüketimi ile ilgili lojistik regresyon analiz sonuçları belirtilmiştir. Hane halklarının margarin tüketiminde etkili olan unsurların belirlenmesi amacıyla oluşturulan modelde kullanılan değişkenlere ait katsayıların birbirinden farklı istatistiksel olarak anlamlı bulunmuştur $\quad(p=0.000)$. Modeldeki bağımsız değişkenlerin bağımlı değişkeni açıklama oranı \%19.6'dır. Oluşturulan modelin geçerliliğini sınamak için Hosmer Lemeshow testi kullanılmıştır. Bu test sonucunda Ki-Kare değeri 7.816, P $=0.452>0.05$ olarak hesap edilmiş ve kurulan modelin uygun olduğu belirlenmiştir.
Belirlenen önem seviyesinde istatistiki olarak anlamlı bulunan ve katsayısı pozitif olan değişkenler, tüketicilerin margarin tüketme davranışlarını etkilediğini ve tüketimde artış olduğunu ifade etmektedir. Aynı şekilde istatistiki olarak anlamlı bulunan ve katsayısı negatif olan değişkenler ise margarin tüketme eğiliminde azalış olduğunu göstermektedir.

Araştırma bulgularına göre tüketicilerin cinsiyet ile margarin tüketimi arasında ters yönlü ve istatistiki olarak \%5 düzeyinde anlamlı bir ilişki olduğu belirlenmiştir. Cinsiyetteki bir birimlik artı̧ margarin tüketme eğilimini $\% 42.6$ oranında azaltmaktadır. 
Ailedeki dokuz yaş altı ve altmış yaş üzeri tüketiciler ile margarin tüketimi arasında pozitif ilişki bulunurken, kırk yaş altı tüketiciler ile margarin tüketimi arasında negatif yönlü bir ilişki vardır. Ancak bu ilişki istatistiki açıdan anlamlı çıkmadığı için yorum yapmaktan kaçınılmıştır.

Doğum yeri büyükşehir olan tüketiciler ile margarin tüketimi arasında pozitif ve istatistiki olarak \%1 düzeyinde anlamlı bir ilişki olduğu belirlenmiştir. Büyükşehirde yaşayan tüketici sayısındaki 1 birimlik artış margarin tüketme olasılı̆ını \%103.30 artırmaktadır.

Eğitim düzeyi ortaokul altı olan ve medeni durumu evli çocuklu olan tüketiciler ile margarin tüketimi arasında negatif yönlü bir ilişki bulunmakla birlikte istatistiki açıdan bu ilişki anlamlı bulunmadığı için yorumlamaktan kaçınılmıştır.

Düşük gelir grubundaki tüketiciler ile margarin tüketme eğilimi ters yönlü ve istatistiki olarak \%10 düzeyinde anlamlı bir ilişki olduğu belirlenmiştir. Düşük gelirdeki bir birimlik artış margarin tüketme eğilimini \%47.2 oranında azaltmaktadır. Bu durumda tüketicilerin gelir düzeyi arttıkça margarin tüketimleri azalmaktadır.

Yüksek gelir grubundaki tüketiciler ile margarin tüketimi arasında pozitif yönlü ve istatistiksel olarak $\% 5$ düzeyinde anlamlı bir ilişki olduğu tespit edilmiştir.
Yüksek gelirdeki bir birimlik artış margarin tüketme olasılı̆ıını \%424 düzeyinde artırmaktadır.

Hane büyüklüğü ile margarin tüketimi arasında pozitif yönlü ve istatistiki olarak \%1 düzeyinde anlamlı bir ilişki olduğu belirlenmiştir. Hane genişliğinde bir birimlik artış margarin tüketme olasılığını \%55.90 artırmaktadır.

Nitekim Pan ve ark. (2008) Hindistan'da yemek alışkanlığı, yeri, hane reisinin eğitimi ve diğer demografik değişkenlerin, yenilebilir yağların seçimi üzerinde önemli etkilere sahip olduğunu bulmuşlardır. Akbay (2007), Türkiye'de hanelerde gelir düzeyinin artması ile margarinin payının azaldığını saptamıştır. Irmak ve Ercan (2016)'da Türkiye'de margarin tüketimini etkileyen faktörlerin; hanehalkı büyüklüğü, kır kent durumu, müstakil konut sahipliği, hanehalkı reisinin eğitim düzeyi, yaşı, cinsiyeti ve sigorta durumu, hanede sıfır beş yaş arası bireyin olması durumu, bankaya ulaşma durumu ve gelir düzeyi olduğunu tespit etmişlerdir. Polat (2010), margarin tüketicilerini yeteri derecede dengeli beslenme alışkanlıklarına sahip olmayan tüketiciler olarak tanımlamıştır. Tüketicilerin yaşı arttıkça ve evli olduğu sürece margarini tercih etme olasılığının azaldığını ifade etmiştir.

Çizelge 12. Margarin tüketimi lojistik regresyon analizi sonuçları

Table 12. Margarine consumption logistic regression analysis results

\begin{tabular}{|c|c|c|c|c|c|}
\hline Değişkenler & Katsayı & Standart hata & Wald değeri & Anlamlılık düzeyi & $\begin{array}{l}\text { Odds oranı } \\
\operatorname{Exp}(B)\end{array}$ \\
\hline Sabit (C) & -4.022 & 1.045 & 14.811 & 0.000 & 0.018 \\
\hline Cinsiyet & -0.555 & 0.263 & 4.450 & $0.035 * *$ & 0.574 \\
\hline Yaş (1) & 0.028 & 0.343 & 0.006 & 0.936 & 1.028 \\
\hline Yaş (2) & -0.238 & 0.317 & 0.566 & 0.452 & 0.788 \\
\hline Yaş (3) & 0.637 & 0.392 & 2.651 & 0.103 & 1.892 \\
\hline Doğum yeri & 0.709 & 0.245 & 8.388 & $0.004^{*}$ & 2.033 \\
\hline Ĕgitim & -0.407 & 0.288 & 1.994 & 0.158 & 0.666 \\
\hline Medeni durum & -0.211 & 0.399 & 0.279 & 0.597 & 0.810 \\
\hline Gelir (1) & -0.638 & 0.338 & 3.560 & $0.059 * * *$ & 0.528 \\
\hline Gelir (2) & 1.656 & 0.667 & 6.174 & $0.013 * *$ & 5.240 \\
\hline Hane büyüklüğü & 0.444 & 0.138 & 10.429 & $0.001^{*}$ & 1.559 \\
\hline Hane harcaması & 0.000 & 0.000 & 2.732 & $0.098 * * *$ & 1.000 \\
\hline Gıda harcaması & 0.000 & 0.000 & 1.669 & 0.196 & 1.000 \\
\hline \multicolumn{6}{|c|}{ Nagelkerke R kare $=0.196$} \\
\hline \multicolumn{6}{|c|}{-2 Log Likelihood $=434.070$} \\
\hline \multicolumn{6}{|c|}{$\underline{x} 2=7.816 p=0.452$ (Hosmer and Lemeshow test) } \\
\hline$\chi_{2}=58.826 p=0.0$ & bus te: & & & & \\
\hline
\end{tabular}

Sonuç olarak, margarin tüketimini etkileyen değişkenlerin incelendiğinde analizde modele dâhil edilen değişkenlere ait katsayıların birbirinden farklı olduğu tespit edilmiş ve istatistiksel olarak anlamlı olduğu belirlenmiştir. Modelde bağımsız değişkenler, bağımlı değişkenin \%19.6'sını açıklamaktadır. Tüketicilerin doğum yeri, yüksek gelir grubu, hane büyüklüğü ve hane harcaması ile margarin tüketim 
eğilimi arasında pozitif ve istatistiksel olarak anlamlı bir ilişki olduğu belirlenmiştir. Cinsiyet ve düşük gelir ile margarin tüketim eğilimi arasında ters yönlü istatistiksel olarak anlamlı bir ilişki olduğu saptanmıştır. 9 ve 40 yaş altı, 60 yaş üzeri, medeni durum ve gıda harcaması ile margarin tüketim eğilimi arasındaki ilişki anlamsız bulunmuştur. Diğer yağ türlerine göre margarin tüketimi azdır. Tüketiciler margarin yağını sağlığa yararlı bulmamaktadır. Dolayısıyla bu konuda bilinçlendirilmelidir. Üretici firmalar gerekli bilgilendirmeyi tüketiciye aktarmalıdırlar.

\section{ÖZET}

Amaç: Bu çalışmada, Konya ili merkez ilçelerinde (Selçuklu, Meram, Karatay) hanelerde margarin tüketiminde tüketici tercihlerini etkileyen faktörler belirlenmiştir.

Yöntem ve Bulgular: Bu araştırmada, araştırma alanı olarak Konya ilinin merkez ilçeleri (Selçuklu, Meram, Karatay) seçilmiştir. Veriler yüz yüze anketlerle elde edilmiş ve toplam 384 kişiyle görüşülmüştür. Araştırma verileri Nisan 2019 dönemine aittir. Illk olarak hanelerin sosyo-ekonomik göstergeleri incelenmiştir. Tüketicilerde margarin tüketimini etkileyen faktörleri araştırmak için lojistik regresyon analizi yapılmıştır.

Genel Yorum: Tüketicilerin margarin tüketim oranı \%34.11'dir. Logistik regresyon analizi sonuçlarına göre, tüketicilerin doğum yeri, yüksek gelir grubu, hane büyüklüğü ve hane harcaması ile margarin tüketim eğilimi arasında pozitif ve istatistiksel olarak anlamlı bir ilişki olduğu belirlenmiştir. Cinsiyet ve düşük gelir ile margarin tüketimi eğilimi arasında ters yönlü istatistiksel olarak anlamlı bir ilişki olduğu saptanmıştır.

Çalışmanın Önemi ve Etkisi: Margarin tüketimi ile ilgili çalışmalar sınırlıdır. Bu durum çalışmanın özgünlüğünü artırmaktadır. Margarin tüketimine etki eden faktörler lojistik regresyon ile analiz edilmiştir. Çalışma margarin tüketicileri kadar üretim yapan firmalar içinde önemlidir.

Anahtar Kelimeler: Margarin, tüketim, lojistik regresyon analizi, tüketici, Konya.

\section{TEŞEKKÜR}

Bu çalışma Pelin AVCl'nın Yüksek Lisans tezinin bir bölümüdür. Araştırmamıza katkıda bulunan tüketicilere teşekkür ederiz.

\section{ÇIKAR ÇATIŞMA BEYANI}

Makale yazarları aralarında herhangi bir çıkar çatışması olmadığını beyan ederler.

\section{ARAŞTIRMACILARIN KATKI ORANI BEYANI}

Yazarlar makaleye eşit oranda katkı sağlamış olduklarını beyan ederler.

\section{KAYNAKLAR}

Akbay C (2005) Kahramanmaraş'ta hanehalklarının gıda tüketim talebi ekonometrik analizi. KSÜ Fen ve Müh. Derg. 8(1): 114-121.

Akbay C (2007) Urban households' cooking oil and fat consumption patterns in Turkey: Quality vs. quantity. Qual. Quant. 41(6): 851-867.

Aktaş C, Erkuş O (2009) Lojistik regresyon analizi ile Eskişehir'in sis kestiriminin incelenmesi. ітісї Fen Bilim. Derg. 8(16): 47-59.

Ali Z, Aslam M, Rasool S (2013). Factors affecting consumption of edible oil in Pakistan. IOSR Journal of Business and Management 15(1): 87-92.

Azabağaoğlu MÖ, İnan ï, Gaytancıoğlu O, Unakıtan G (2003) Tüketicilerin bitkisel sıvıyağ ve margarin satın alma davranışlarının analizi. Türkiye I. Yağlı Tohumlar, Bitkisel Yağlar ve Teknolojileri Sempozyumu, Mayıs 22-23, İstanbul, Türkiye. pp 22-23.

Baltacı A (2011) Amaca yönelik pazarlama çabalarının tüketicilerin margarin markası seçimine etkisi ve ankara ili keçiören ilçesi süpermarketlerinde yapılan uygulama. Yüksek Lisans Tezi, Anadolu Üniversitesi, S. Bil. Enst. $145 \mathrm{~s}$.

Beyhan Y (2004) Çalışma hayatı sağlık riskleri ve beslenme. türk tabipleri birliği işyeri hekimliği ders notları. 8. bs. p.307-326.

Bircan H (2004) Lojistik regresyon analizi: Tıp verileri üzerine bir uygulama. KOÜ SBiED 8(2): 185-208.

ÇBS (2020) Sanayiden kaynaklanan hava kirliliğinin belirlenmesi ve azaltılmasına yönelik uygulamanın kolaylaştırılmasının sağlanması projesi-bitkisel yağ üretimi-sektörel uygulama kılavuzu. T.C. Çevre ve Şehircilik Bakanlı̆̆ı, Ankara. 12s.

Gündüz O, Esengün K (2010) Ailelerin bitkisel yağ tüketimleri üzerine bir araştırma. KMUSEKAD 2: 6772.

Hosmer DW, Lemeshow S (1980) Goodness of fit tests for the multiple logistic regression model. Commun. Stat. A 9(10): 1043-1069.

Irmak S, Ercan U (2016) Veri madenciliği ile hanehalkı margarin tüketimini etkileyen sosyoekonomik, demografik ve hanehalkı karakteristiklerinin belirlenmesi. Xth International Statistics Days Conference (ISDC'2016), Oct 07-09, Giresun, Turkey. pp 465-476. 
Kadakoğlu B, Karlı B (2019) Türkiye'de yağlı tohum üretimi ve dış ticareti. Akademik Sos. Araş. Derg. 7(96): 324-341.

Karlı B, Kadakoğlu B, Gül M (2018) Dünya ve Türkiye'de pamuk üretimi ve dış ticaret yapısı. V. International Multidisciplinary Congress of Eurasia, July 24-26, Barcelona, İspanya. pp 129-136.

Kim D (2008) Demand and pricing in the US margarine industry. JAFIO 6(1):1-19.

Köksal O (1993) İşçi beslenmesi ve işyeri hekiminin beslenme konusunda görevleri türk tabipleri birliği iş hekimliği ders notları. 3. baskı. Maya Matbaacılık, p. 295-314.

Milli Eğitim Bakanlığı (MEB) (2016) Tarım yağ bitkileri. T.C. Milli Eğitim Bakanlığı, Ankara, 73 s.

Miran B (2011) Temel istatistik. Ege Üniversitesi Basımevi, İzmir, 302 s.

Oğan Y, Küçükkömürler S (2018) Yiyecek içecek işletmelerinde yağ kullanımı; Arhavi örneği. Güncel Turizm Araş. Derg. 2(1): 602-615.

Özer EA, Dede S, Dursun A, Avşar YK (2016) gıda piramitleri. fonksiyonel beslenme (Eds. Güzel Seydim ZB), Sidas Yayıncılık, İzmir. pp 13-30.

Öztekin EÖ (2006) Tekirdağ ilinde bitkisel yağ ürünlerinde tüketici eğilimleri ve müşteri memnuniyet analizi. Yüksek Lisans Tezi, Trakya Üniversitesi, Fen Bil. Enst., 82 s.
Pan S, Mohanty S, Welch M (2008). India edible oil consumption: A censored incomplete demand approach. J. Agric. Appl. Econ. 40(3): 821-835.

Polat F (2010) Yemeklik yağ sektöründe tüketici davranışlarını etkileyen faktörlerin analizi. Doktora Tezi, Ankara Üniversitesi, Fen Bil. Enst., 198 s.

Sizege Ç (2017) Multinomial probit modelinde bayes yaklaşımı: Türkiye'de yağ tüketim tercihinin incelenmesi. TÜ SBD 19(2): 441-459.

Sözen S, Bilir N, Yıldız AN, Yıldız E, Sözen T (2009). Metal sektöründe bir işyerinde çalışanların beslenme alışkanlıkları ve ilişkili antropometrik ölçümleri. THB 28(3): 7-14.

Şengül S (2002) Türkiye'de kentsel ve kırsal kesimde gelir gruplarına göre gıda talebi. UÜ iiBF Dergisi 21(1): 257282.

Torun S (2013) Kozmetik amacıyla kullanılan bazı bitkisel yağların yağ asidi bileşimlerinin analizi. Yüksek Lisans Tezi, Gazi Üniversitesi, Fen Bil. Enst. 67 s.

Tosun M (2003) Bitkisel sıvı yağlar sektör araştırması. Türkiye Kalkınma Bankası A.Ş. Yayınları, Araştırma Müdürlüğü. Genel Araştırmalar 3: (1-2), Ankara.

Yen ST, Kan K, Su SJ (2002) Household demand for fats and oils: two-step estimation of a censored demand system. Appl. Econ. 34(14): 1799-1806. 